\title{
Land use change decreases soil carbon stocks in Tibetan grasslands
}

\author{
Na Qiao • Xingliang Xu • Guangmin Cao • \\ Hua Ouyang • Yakov Kuzyakov
}

Received: 29 January 2015 / Accepted: 4 June 2015 / Published online: 16 June 2015

(C) Springer International Publishing Switzerland 2015

\begin{abstract}
Backgrounds and aims Land use is an important factor affecting soil organic carbon (SOC) dynamics and can produce positive $\mathrm{C}$ climate feedback, but its effects remain unknown for Tibetan ecosystems.

Methods Recent land use changes have converted the traditional winter Kobresia pastures of nomads in the northeastern Tibetan Plateau to Elymus pastures or even to cropland. Detailed SOC measurements up to $30-\mathrm{cm}$ depth were combined with analysis of $\delta^{13} \mathrm{C}, \delta^{15} \mathrm{~N}$, bulk density, microbial $\mathrm{C}$, and $\mathrm{N}$ contents in three land use types. Results Bulk density was decreased by conversion from Kobresia pasture to cropland but increased by conversion to Elymus pasture. The loss of $1 \%$ of SOC caused by land use change leads to $\delta^{13} \mathrm{C}$ increase of $0.8 \%$. Conversion to cropland significantly decreased SOC stocks $(10 \%)$ and microbial biomass $\mathrm{C}$, but the $\mathrm{C}$ loss
\end{abstract}

Responsible Editor: Johan Six.

N. Qiao

Key Laboratory of Tropical Forest Ecology, Chinese Academy of Sciences, Xishuangbanna Tropical Botanical Garden, Menglun Mengla, Yunnan 666303, China

X. Xu $(\bowtie) \cdot H$. Ouyang $\cdot$ Y. Kuzyakov

Key Laboratory of Ecosystem Network Observation and Modeling, Chinese Academy of Sciences, Institute of Geographic Sciences and Natural Resources Research, 11A Datun Road, Chaoyang District, Beijing 100101, China e-mail: xuxingl@hotmail.com

G. Cao

Northwest Institute of Plateau Biology, Chinese Academy of Sciences, NO. 23 Xinning Road, Xining 810008, China
$(1.6 \%)$ was insignificant in Elymus pasture. Land use changes strongly increased soil $\delta^{15} \mathrm{~N}$ in the top $5 \mathrm{~cm}$. Conclusions Conversion to Elymus pasture did not change the $\mathrm{C}$ stocks, but conversion to cropland decreased $\mathrm{C}$ stocks by $10 \%$ within 10 years. Soil $\delta^{13} \mathrm{C}$ and $\delta^{15} \mathrm{~N}$ data indicate acceleration of $\mathrm{C}$ and $\mathrm{N}$ cycling due to the replacement of Kobresia pasture by Elymus pasture and cropland.

Keywords Alpine meadow $\cdot$ Pasture $\cdot$ Cropland $\cdot$ Soil organic carbon $\cdot$ Total nitrogen $\cdot \delta^{13} \mathrm{C} \cdot \delta^{15} \mathrm{~N}$

\section{Introduction}

Soil carbon (C) is the largest terrestrial organic $\mathrm{C}$ pool, globally containing $3300 \mathrm{Pg} \mathrm{C}$ (Tarnocai et al. 2009;

N. Qiao

University of the Chinese Academy of Sciences, 19A Yuquan Road, Beijing 100049, China

Y. Kuzyakov

Department of Soil Science of Temperate Ecosystems and Department of Agricultural Soil Science, University of Göttingen, Göttingen, Germany

Y. Kuzyakov Institute of Environmental Sciences, Kazan Federal University, Kazan, Russia 
German et al. 2011), four times larger than the atmospheric $\mathrm{C}$ pool and five times larger than the vegetation $\mathrm{C}$ pool. Consequently, even small changes in the soil organic $\mathrm{C}$ (SOC) pool would have large effects on atmospheric $\mathrm{CO}_{2}$ and produce potential feedbacks to climate (Kirschbaum 2004; Heimann and Reichstein 2008; Cotrufo et al. 2011; Stockmann et al. 2013). Land use change is one of the most important factors strongly affecting SOC stocks and dynamics on earth (Jendinson et al. 1991; Stockmann et al. 2013; Guillaume et al. 2015). Therefore, understanding how land use changes affect SOC dynamics is important to clarify feedbacks to climate (Stockmann et al. 2013).

Grasslands are one of the most important vegetation types on earth, covering approximately $40 \%$ of the earth's land surface (LeCain et al. 2002; Wang and Fang 2009). Global grasslands store about $308 \mathrm{Pg} \mathrm{C}$, with $92 \%$ of that in soils (Houghton 1995), indicating that grasslands may have great potential to store a considerable fraction of atmospheric $\mathrm{CO}_{2}$ as organic $\mathrm{C}$ in the soil (Reid et al. 2004). However, recent studies have suggested that large areas of grasslands have suffered soil C losses due to land use change to cropland or intensive pastures. Globally, approximately $6.60 \times 10^{8}$ ha of grasslands has been converted to cropland (Geist 2006). In the past 20 years (from 1990 to 2010), the grassland area used for pasture and cultivation in China was estimated to exceed $5.3 \times 10^{6}$ ha (Liu et al. 2014). These land use changes can strongly alter $\mathrm{C}$ cycling with consequences for C stocks (Hafner et al. 2012; Unteregelsbacher et al. 2012). Soil $C$ is lost at the rate of $1-2 \%$ of the $C$ stock per year during decades after land use changes from grasslands to agriculture (Newton et al. 1945). This means that about $20-30 \%$ of SOC can be lost due to grassland conversions to cropland within 2-3 decades (WBGU Special Report 1998). So far, a total of 77 Pg soil $\mathrm{C}$ has been lost due to grassland conversions to cropland worldwide (Geist 2006). There are three main mechanisms that could increase SOC decomposition after conversion: (1) plowing leading to better aeration, (2) removal of plant biomass by annual harvesting or grazing, and (3) decrease of belowground $\mathrm{C}$ input by roots and rhizodeposition. Additionally, other processes such as changes of water budget (Sanaullah et al. 2011), aggregate destruction (Chen et al. 2007), fertilization, and decreasing soil $\mathrm{C} / \mathrm{N}$ ratio may be important for soil C losses.

The Tibetan Plateau covers about 2.6 million $\mathrm{km}^{2}$ (Zhang et al. 2002). Alpine steppes cover an area of
$800,000 \mathrm{~km}^{2}$ in the northwest of the Tibetan Plateau (Zhang 1988; Miehe et al. 2011), and Kobresia pastures cover an area of $450,000 \mathrm{~km}^{2}$ in the southeast (Miehe et al. 2008). Those Kobresia pastures are partly secondary grasslands after forests had been cleared since the mid-Holocene (Kaiser et al. 2007; Miehe et al. 2009, 2014). About 7.4 Pg C is estimated to be stored in the upper $1 \mathrm{~m}$ of Tibetan grasslands (Yang et al. 2008). Because of recently enhanced human activities and various sedentarization programs, larger parts of the Kobresia pastures are classified as degraded, and, partly, they have been converted to cropland.

Compared with temperate grasslands, however, only a few studies assessed SOC stocks and C fluxes depending on land use systems in Tibetan Plateau ( $\mathrm{Li}$ et al. 2006; Wang et al. 2011; Ingrisch et al. 2015) and their effects on SOC dynamics in these montane grasslands (Babel et al. 2014). Previous studies mostly explored SOC dynamics through measuring SOC contents, a technique that does not allow conclusions about the mechanisms of SOC decrease. Additionally, land use changes can induce shifts in plant functional diversity and community structure. Consequently, these shifts lead to differences in plant litter compounds and thus modify SOC decomposition and storage. During microbial decomposition, isotope discrimination occurs (Šantrůčková et al. 2000; Bowling et al. 2008). The light isotope (e.g., C and $\mathrm{N}$ ) is respired, and the heavy isotope (e.g., $\mathrm{C}$ and $\mathrm{N}$ ) is assimilated into biomass that is subsequently deposited in the soil organic matter. Consequently, isotopic enrichment occurs and reflects increased decomposition of soil organic matter. Therefore, we combined direct measurements of SOC with soil $\delta^{13} \mathrm{C}$ and $\delta^{15} \mathrm{~N}$ as well as microbial biomass $\mathrm{C}$ and $\mathrm{N}$ contents to analyze the mechanisms of $\mathrm{C}$ and $\mathrm{N}$ losses (Guillaume et al. 2015). To achieve more detailed information regarding the effects of land use on SOC, we analyzed soil samples at 5-cm intervals up to $30-\mathrm{cm}$ depth. The aim of the study was to clarify the effects and mechanisms of land use change on SOC dynamics and stocks in these Kobresia grasslands on the Tibetan Plateau.

\section{Materials and methods}

Research site

The study was conducted at the Haibei Alpine Meadow Ecosystem Station of the Chinese Academy of Sciences, 
Qinghai Province $\left(37^{\circ} 36^{\prime} \mathrm{N}, 101^{\circ} 19^{\prime} \mathrm{E}, 3215 \mathrm{~m}\right.$ above sea level). At the site, the 25 -year mean for precipitation is $600 \mathrm{~mm}$ per year. The growing season starts from around April 22 and ends around October 12, with approximately 143 growing days (Li et al. 2004). Dominant plant species in Kobresia pastures include Kobresia humilis Serg., Stipa aliena Keng., Poa sp., Festuca ovina Linn., Gentiana aristata Maxim., Gentiana straminea Maxim., Saussurea superba Anth., and Gueldenstaedtia diversifolia Maxim. (Zhou 2001). The soil is classified as Mat-Cryic Cambisol (Chinese Soil Taxonomy Research Group 1995), corresponding to Gelic Cambisol (WRB 1998).

\section{Land use types}

At the Haibei research station, Kobresia pastures are often changed to Elymus pastures and croplands. To explore the effects of land use change on montane SOC dynamics, we chose three most common land use types: Kobresia pasture, Elymus pasture, and cropland. These three land uses are in similar positions within the flat landscape and on the same soil type.

Kobresia pasture was in general not used for grazing and not fertilized in the past decade. Ten years ago, both Elymus pasture and cropland had been converted from the Kobresia pasture. Cropland was cropped with oat (Avena sativa). The seeds of $A$. sativa were scattered each May after plowing (approximately $20-\mathrm{cm}$ depth). Organic manure was used in the cropland at a rate less than $50 \mathrm{~kg} \mathrm{~N} \mathrm{ha}^{-1}$. Aboveground biomass of A. sativa was harvested every year, and thereafter, the cropland was left bare in winter. The Elymus pasture was established with Elymus nutans. The seeds of E. nutans were scattered only once at the beginning of its establishment. There was no any fertilization during the whole growing period, and this type of pasture was used as winter grazing.

Three plots $(30 \mathrm{~m} \times 30 \mathrm{~m})$ for each land use type were randomly selected, with the distance of over $100 \mathrm{~m}$ between them that assured independence of replicates. The manure had a $\delta^{13} \mathrm{C}$ of $-25.8 \%$ and a $\delta^{15} \mathrm{~N}$ of $0.5 \%$. $K$. humilis showed a $\delta^{13} \mathrm{C}$ of $-26.4 \%$, E. nutans with $-26.8 \%$ and $A$. sativa with $-27.1 \%$.

\section{Soil sampling}

To collect soil, three subplots $(5 \mathrm{~m} \times 5 \mathrm{~m})$ were randomly placed in each replicate plot. Soil samples were taken from a pit $(50 \mathrm{~cm} \times 50 \mathrm{~cm})$ located at the center of each subplot, at 5-cm intervals up to $30 \mathrm{~cm}$ in depth. Soil from each layer of the three subplots in a replicate plot was mixed together. After collection, soil samples were immediately transferred to the laboratory. Living roots were carefully removed from the soil and were sieved to $<2 \mathrm{~mm}$. A subsample of $20 \mathrm{-g}$ fresh soil was dried at $75^{\circ} \mathrm{C}$ for $48 \mathrm{~h}$ and was ground to a fine powder using a ball mill (MM200, Retsch, Haan, Germany). The remaining soil was stored at $-20^{\circ} \mathrm{C}$ for microbial biomass measurements.

\section{Analyses}

Soil bulk density was determined by core cutter method. Ground soil was weighed into tin capsules and analyzed for total $\mathrm{C}, \mathrm{N}, \delta^{13} \mathrm{C}$, and $\delta^{15} \mathrm{~N}$ by continuous-flow isotope ratio mass spectrometry coupled with an elemental analyzer (EA 1110; CE Instruments, Milan, Italy) (EA-IRMS) and a ConFlo II device connected to IRMS (FinniganMAT 253, Bremen, Germany). The $\delta^{13} \mathrm{C}$ and $\delta^{15} \mathrm{~N}$ abundance in soil is expressed in $\delta$ units as related to $\mathrm{V}_{\mathrm{PDB}}$ standard.

Microbial biomass $\mathrm{C}$ was measured after chloroform fumigation and extraction of dissolved organic $\mathrm{C}$ (Vance et al. 1987). Microbial biomass $C$ was estimated from the difference between total organic $\mathrm{C}$ in the extracts from fumigated and non-fumigated soils, with a $k_{\mathrm{EC}}$ factor of 0.45 (Wu et al. 1990). Microbial biomass $\mathrm{N}$ was estimated from the difference in total $\mathrm{N}$ from the extracts of fumigated and non-fumigated soils, with a $k_{\mathrm{EN}}$ factor of 0.54 (Brookes et al. 1985).

Calculations and statistics

Soil organic $\mathrm{C}$ stock $\left(\mathrm{kg} \mathrm{C} \mathrm{m}^{-2}\right)$ was calculated as a sum of SOC amounts (SOC content multiplied by bulk density and the thickness of soil layer) in each layer up to $30 \mathrm{~cm}$ (Wu et al. 2003). The standard errors of means are presented in figures. Two-way analysis of variance (ANOVA) was used to estimate the effect of land use and soil depth on SOC, total $\mathrm{N}$, microbial biomass $\mathrm{C}$ and $\mathrm{N}$, as well as soil $\delta^{13} \mathrm{C}$ and $\delta^{15} \mathrm{~N}$. One-way ANOVA was used to estimate the effect of land use on stocks of SOC and microbial biomass $\mathrm{C}$. Linear regression was used to correlate SOC and total $\mathrm{N}$, microbial biomass $\mathrm{N}$ or soil $\delta^{13} \mathrm{C}$. Linear regression was also used to correlate $\log \mathrm{SOC} \%$ and soil $\delta^{13} \mathrm{C}$ for each land use type for 
estimation of SOC turnover (Garten 2006; Guillaume et al. 2015), as well as to assess the increase of $\delta^{13} \mathrm{C}$ $\left(\Delta \delta^{13} \mathrm{C}\right)$ and the decrease of SOC $(\Delta \mathrm{SOC})$ caused by land use changes from grassland to cropland or Elymus pasture. All statistical analyses were performed with SPSS 16.0 software (SPSS Inc., Chicago, IL, USA). All differences were tested for significance at $P=0.05$.

\section{Results}

Effects of land use change on soil bulk density, SOC, and total $\mathrm{N}$

Land use change affected bulk density, SOC, and total $\mathrm{N}$, and these effects were dependent on land use and soil depth (Fig. 1, Table 1). The bulk density ranged between 0.69 and $1.19 \mathrm{~g} \mathrm{~cm}^{-3}$ for Kobresia pasture, between 1.02 and $1.20 \mathrm{~g} \mathrm{~cm}^{-3}$ for Elymus pasture and between 0.81 and $1.12 \mathrm{~g} \mathrm{~cm}^{-3}$ for cropland. In the upper $5 \mathrm{~cm}$, conversion from Kobresia pasture to Elymus pasture and cropland significantly increased bulk density. Below the 5-cm depth, the conversion to Elymus pasture increased density while the conversion to cropland decreased density. In Kobresia pasture, bulk density increased with depth from $0.69 \pm 0.04 \mathrm{~g} \mathrm{~cm}^{-3}$ at the upper 5-cm depth to $1.19 \pm 0.02 \mathrm{~g} \mathrm{~cm}^{-3}$ at the 30 -cm depth. A steep increase was observed from the top 5-cm depth to the 10-cm depth (Fig. 1).

SOC ranged between 3.84 and $7.37 \%$ for Kobresia pasture, between 4.30 and $5.52 \%$ for Elymus pasture, and between 4.46 and $5.21 \%$ for cropland. Land use

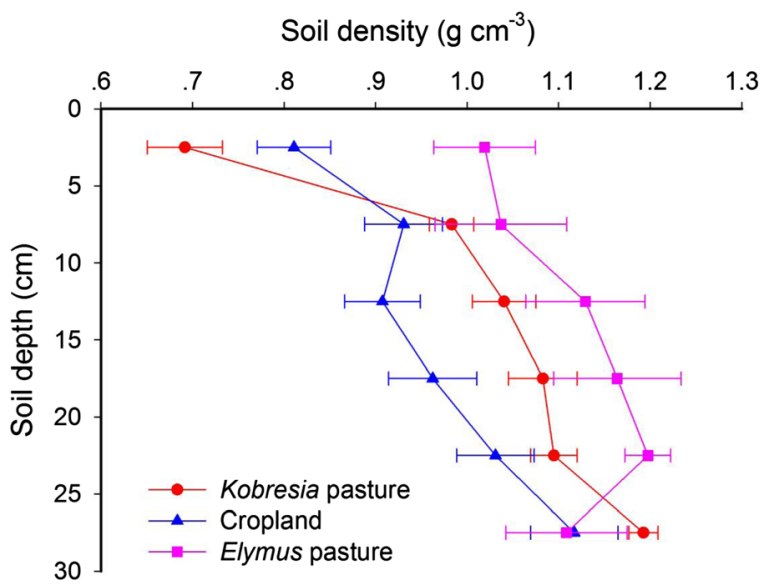

Fig. 1 Soil density in the upper $30 \mathrm{~cm}$ after the conversion from Kobresia grassland to Elymus pasture and cropland (Avena sativa) for 10 years. Each value is means $\pm \mathrm{SE}$ of three replicates change from Kobresia pasture to Elymus pasture, and cropland decreased SOC contents in all depths, except the lowest depth (Fig. 2a). In the upper $5 \mathrm{~cm}$, land use change strongly decreased SOC by about $30 \%$. SOC in pasture from the surface to $20-\mathrm{cm}$ depth was

Table 1 Results of two-way analysis of variance (ANOVA) for the effects of land use types and soil depth on soil bulk density, soil organic carbon (SOC), total nitrogen $(\mathrm{N})$, microbial biomass $\mathrm{C}$ and $\mathrm{N}$, as well as soil $\delta^{13} \mathrm{C}$ and $\delta^{15} \mathrm{~N}$

\begin{tabular}{lllll}
\hline Factors & $\begin{array}{l}\text { Sum of } \\
\text { squares }\end{array}$ & d.f. $F$ & Significance \\
\hline
\end{tabular}

\begin{tabular}{|c|c|c|c|c|}
\hline \multicolumn{5}{|l|}{ Bulk density } \\
\hline Land use type & 0.206 & 2 & 0.103 & $<0.001$ \\
\hline Soil depth & 0.519 & 5 & 0.104 & $<0.001$ \\
\hline Land use type $\times$ soil depth & 0.168 & 10 & 0.017 & 0.019 \\
\hline Errors & 0.235 & 36 & 0.007 & \\
\hline \multicolumn{5}{|l|}{ SOC } \\
\hline Land use type & 4.16 & 2 & 16.7 & $<0.001$ \\
\hline Soil depth & 16.4 & 5 & 26.4 & $<0.001$ \\
\hline Land use type $\times$ soil depth & 8.93 & 10 & 7.18 & $<0.001$ \\
\hline Errors & 4.48 & 36 & & \\
\hline \multicolumn{5}{|l|}{ Total N } \\
\hline Land use type & 0.122 & 2 & 26.1 & $<0.001$ \\
\hline Soil depth & 0.136 & 5 & 11.7 & $<0.001$ \\
\hline Land use type $\times$ soil depth & 0.068 & 10 & 2.91 & 0.009 \\
\hline Errors & 0.084 & 36 & & \\
\hline \multicolumn{5}{|l|}{ Microbial biomass $\mathrm{C}$} \\
\hline Land use type & 141839 & 2 & 5.39 & 0.009 \\
\hline Soil depth & 1721974 & 5 & 26.2 & $<0.001$ \\
\hline Land use type $\times$ soil depth & 518583 & 10 & 3.943 & 0.001 \\
\hline Errors & 473428 & 36 & & \\
\hline \multicolumn{5}{|l|}{ Microbial biomass $\mathrm{N}$} \\
\hline Land use type & 2585 & 2 & 1.73 & 0.191 \\
\hline Soil depth & 88574 & 5 & 23.8 & $<0.001$ \\
\hline Land use type $\times$ soil depth & 19236 & 10 & 2.58 & 0.018 \\
\hline Errors & 26835 & 36 & & \\
\hline \multicolumn{5}{|l|}{ Soil $\delta^{13} \mathrm{C}$} \\
\hline Land use type & 26.8 & 2 & 58.6 & $<0.001$ \\
\hline Soil depth & 34.7 & 5 & 30.3 & $<0.001$ \\
\hline Land use type $\times$ soil depth & 11.5 & 10 & 5.04 & $<0.001$ \\
\hline Errors & 8.23 & 36 & & \\
\hline \multicolumn{5}{|l|}{ Soil $\delta^{15} \mathrm{~N}$} \\
\hline Land use type & 7.50 & 2 & 12.7 & $<0.001$ \\
\hline Soil depth & 3.67 & 5 & 2.48 & 0.050 \\
\hline Land use type $\times$ soil depth & 4.81 & 10 & 1.62 & 0.139 \\
\hline Errors & 10.7 & 36 & & \\
\hline
\end{tabular}




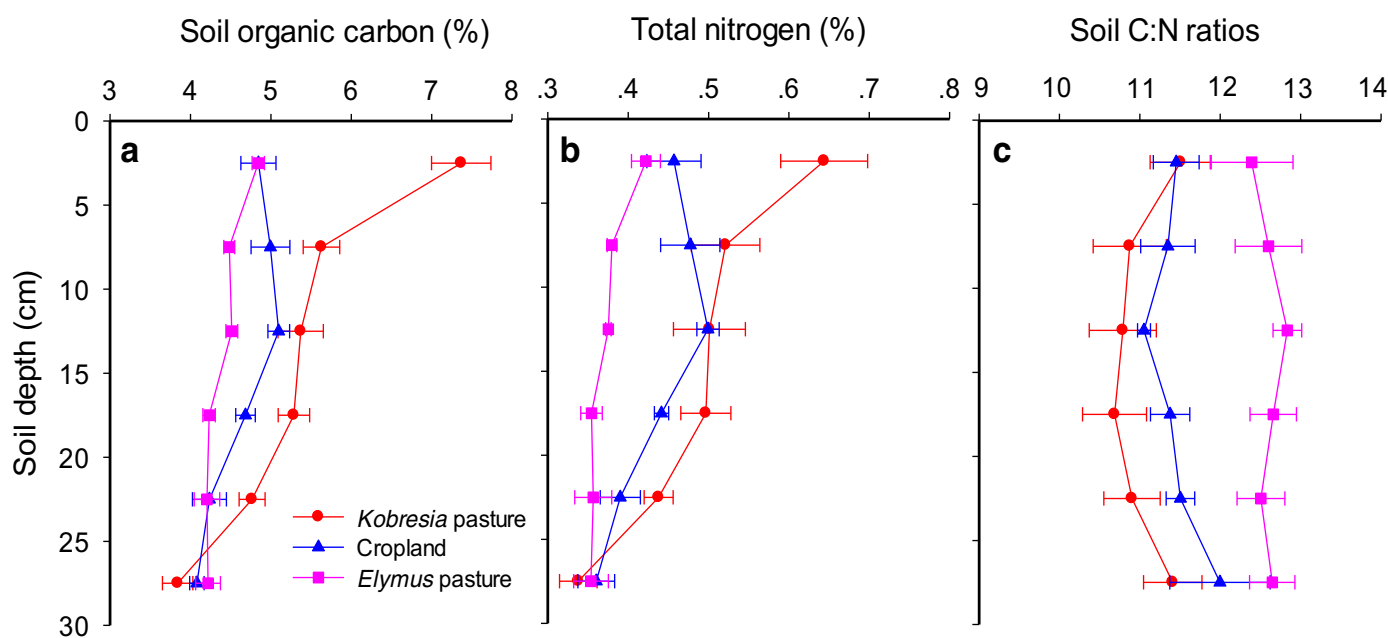

Fig. 2 Soil organic carbon (a), total nitrogen (b), and soil C:N ratios (c) in the upper 30-cm soils after the conversion from Kobresia pasture to Elymus pasture and cropland (Avena sativa) for 10 years. Values are means $\pm \mathrm{SE}$ of three replicates

significantly lower than in Kobresia pasture (Fig. 2a). Along the profile, SOC in Kobresia pasture strongly decreased with depth due to lower $\mathrm{C}$ input by roots below $5 \mathrm{~cm}$. Compared to Kobresia pasture and cropland, SOC in Elymus pasture varied slightly by depth (Fig. 2a). Total $\mathrm{N}$ showed similar patterns as those of SOC among three land use types (Fig. 2b). Land use changes increased soil $\mathrm{C}: \mathrm{N}$ ratios, with the highest values in Elymus pasture and the smallest in Kobresia pasture. Soil C:N ratios in cropland were close to those in Elymus pasture (Fig. 2c).

Effects of land use change on microbial biomass $\mathrm{C}$ and $\mathrm{N}$

Microbial biomass $\mathrm{C}$ ranged between 264 and $1041 \mu \mathrm{g} \mathrm{C} \mathrm{g}^{-1}$ d.w. soil for Kobresia pasture, between 298 and $913 \mu \mathrm{g} \mathrm{C} \mathrm{g}^{-1}$ d.w. soil for Elymus pasture, and between 235 and $506 \mu \mathrm{g} \mathrm{g} \mathrm{g}^{-1}$ d.w. soil for cropland. Land use change showed significant effects on microbial biomass $\mathrm{C}$, but no strong effects on microbial $\mathrm{N}$ (Table 1). Soil depth significantly affected microbial C and $\mathrm{N}$ (Table 1). An especially clear pattern was that the conversion from Kobresia pasture to cropland significantly decreased microbial biomass $\mathrm{C}$ by $50 \%$ in the surface soil, while the conversion to pasture significantly decreased microbial biomass $\mathrm{C}$ in the 5-10-cm layer due to mixture by tillage (Fig. 3a). Along the profile, microbial biomass $\mathrm{C}$ strongly decreased with depth, except the upper $5 \mathrm{~cm}$ for cropland (Fig. 3a). Microbial $\mathrm{N}$ in the three land use types showed similar patterns to those of microbial C (Fig. 3b). Land use changes had no effects on microbial C:N (Fig. 3c).

Effects of land use change on soil $\delta^{13} \mathrm{C}$ and $\delta^{15} \mathrm{~N}$

Soil $\delta^{13} \mathrm{C}$ ranged between -25.6 and $-21.3 \%$ for Kobresia pasture, between -22.8 and $-21.4 \%$ for Elymus pasture, and between -23.7 and $-21.1 \%$ for cropland. Land use and soil depth significantly affected soil $\delta^{13} \mathrm{C}$ and $\delta^{15} \mathrm{~N}$ (Table 1, Fig. 4). The conversion from Kobresia pasture to Elymus pasture strongly increased $\delta^{13} \mathrm{C}$ in SOC (Fig. 4a). With increasing depth, $\delta^{13} \mathrm{C}$ in SOC increased, while cropland showed a slight decrease in the upper $15 \mathrm{~cm}$ due to mixture by tillage (Fig. 4a). In the upper $5 \mathrm{~cm}, \delta^{13} \mathrm{C}$ was lowest $(-25.6 \pm$ $0.3 \%$ o) in grassland, $2.5 \%$ lower than those in Elymus pasture and cropland. The $\delta^{13} \mathrm{C}$ of all three land use types converged to $-21 \%$ at the $30-\mathrm{cm}$ point showing that there were no significant effects of land use changes on SOC below this depth during the 10 years.

Soil $\delta^{15} \mathrm{~N}$ ranged between 4.3 and $5.7 \%$ for Kobresia pasture, between 5.8 and $6.8 \%$ for Elymus pasture, and between 5.5 and $6.5 \%$ for cropland. Land use change from Kobresia pasture to Elymus pasture and cropland increased $\delta^{15} \mathrm{~N}$, except at the $5-10-\mathrm{cm}$ layer. The $\delta^{15} \mathrm{~N}$ values in the surface soil were significantly higher in both Elymus pasture and cropland than those in Kobresia pasture, indicating accelerated N cycling caused by the two land use changes. Along soil depth, the $\delta^{15} \mathrm{~N}$ in Kobresia pasture showed an opposite pattern to that in Elymus pasture (Fig. 4b). 


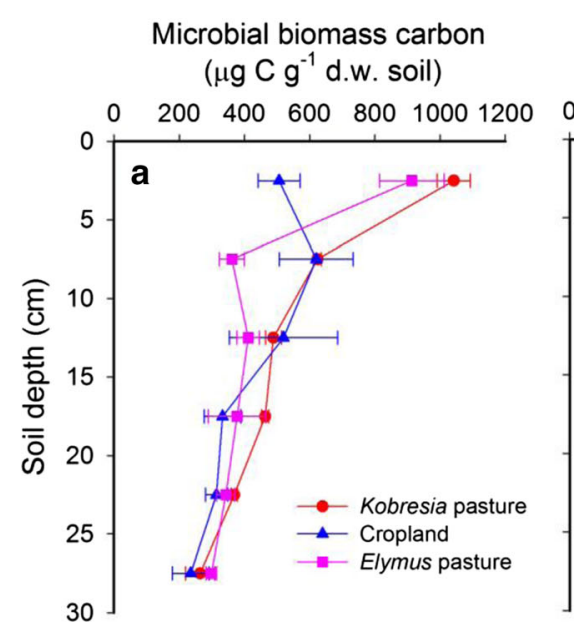

Fig. 3 Microbial biomass carbon (a), microbial biomass nitrogen (b), and $\mathrm{C}: \mathrm{N}$ ratios in microbial biomass (c) in the upper 30-cm soils after the conversion from Kobresia grassland to Elymus

Correlations between soil organic $\mathrm{C}$, microbial biomass $\mathrm{C}$, and $\delta^{13} \mathrm{C}$

Across the three land use types, SOC was strongly correlated with total $\mathrm{N}\left(y=0.10 \mathrm{x}-835, R^{2}=0.88\right.$, Fig. 5a) and microbial biomass $\mathrm{C}\left(y=222 \mathrm{x}+646, R^{2}=0.59\right.$, Fig. $\left.5 b\right)$. Soil $\delta^{13} \mathrm{C}$ significantly decreased with SOC contents $\left(y=-0.0001 \mathrm{x}-15.9, R^{2}=0.77\right.$, Fig. $\left.5 \mathrm{c}\right)$. Soil $\delta^{13} \mathrm{C}$ significantly decreased with $\log$ SOC $\%$ for each land use type in the upper 15-cm depth, with a marginally significant effect between cropland/Elymus pasture and Kobresia pasture $(P=0.058$, Fig. $5 \mathrm{~d})$. We calculated the difference in SOC $(\triangle \mathrm{SOC})$ and in $\delta^{13} \mathrm{C}\left(\Delta\right.$ soil $\left.\delta^{13} \mathrm{C}\right)$ between Kobresia pasture and Elymus pasture/cropland along the profile,
Microbial biomass

\section{$\mathrm{C}: \mathrm{N}$ ratios} ( $\mu \mathrm{g} \mathrm{N} \mathrm{g}^{-1}$ d.w. soil)

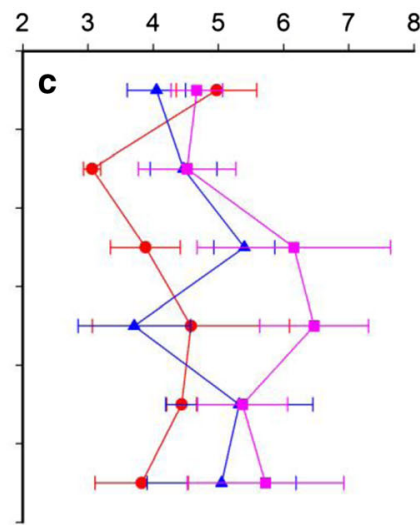

pasture and cropland (Avena sativa) for 10 years. Each value is means \pm SE of three replicates

showing that $\Delta \delta^{13} \mathrm{C}$ was strongly positively correlated with $\triangle \mathrm{SOC}\left(y=0.80 \mathrm{x}+0.50, R^{2}=0.82\right.$, Fig. 6$)$. This means that a decrease of $1 \%$ of SOC led to an increase in $\delta^{13} \mathrm{C}$ of $0.8 \%$. No strong correlations were observed between these variables and soil $\delta^{15} \mathrm{~N}$ (data not shown).

Effects of land use change on $\mathrm{C}$ stocks and the size of microbial biomass $\mathrm{C}$

According to soil bulk density and SOC content in each soil layer, we found the $\mathrm{C}$ stock decreased compared to Kobresia pasture for cropland until 25-cm depth. By comparison, Elymus pasture did not lose $\mathrm{C}$ in the top 5 -cm soil but decreased its $\mathrm{C}$ stock from 5 - to $20-\mathrm{cm}$

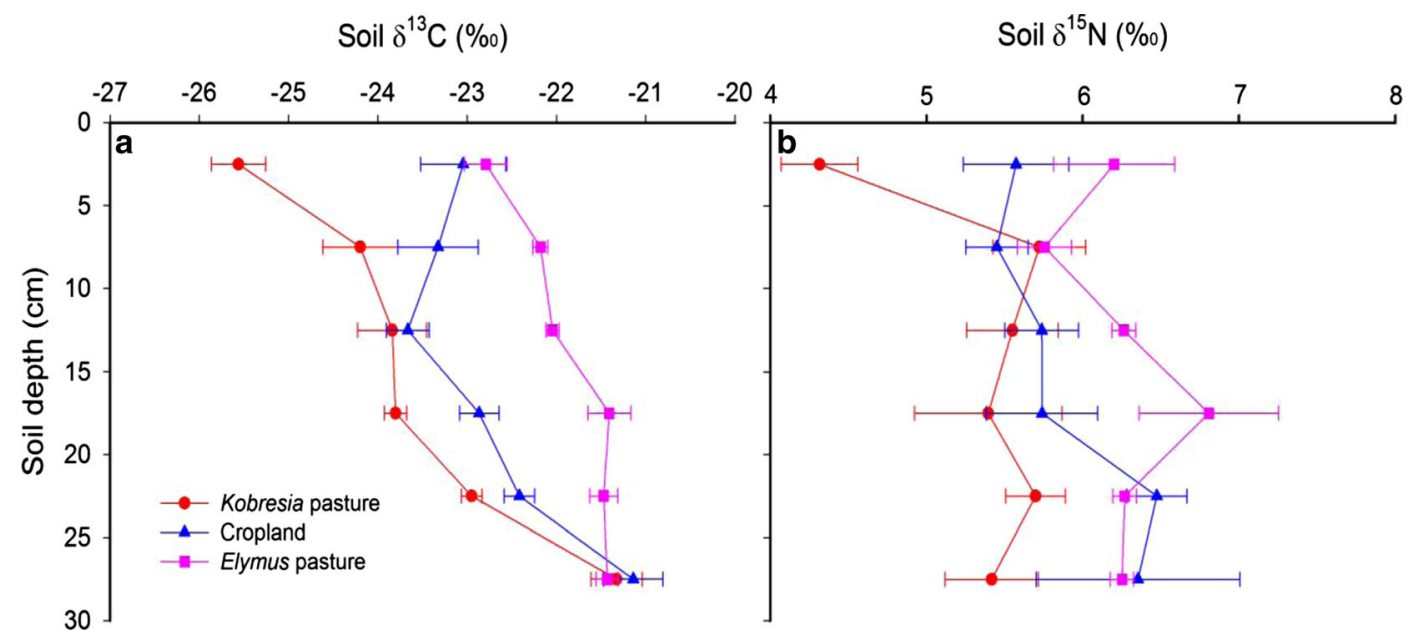

Fig. 4 Soil $\delta^{13} \mathrm{C}$ (a) and $\delta^{15} \mathrm{~N}$ (b) in the upper 30-cm depth after the conversion from Kobresia grassland to Elymus pasture and cropland (Avena sativa) for 10 years. Each value is means $\pm \mathrm{SE}$ of three replicates 

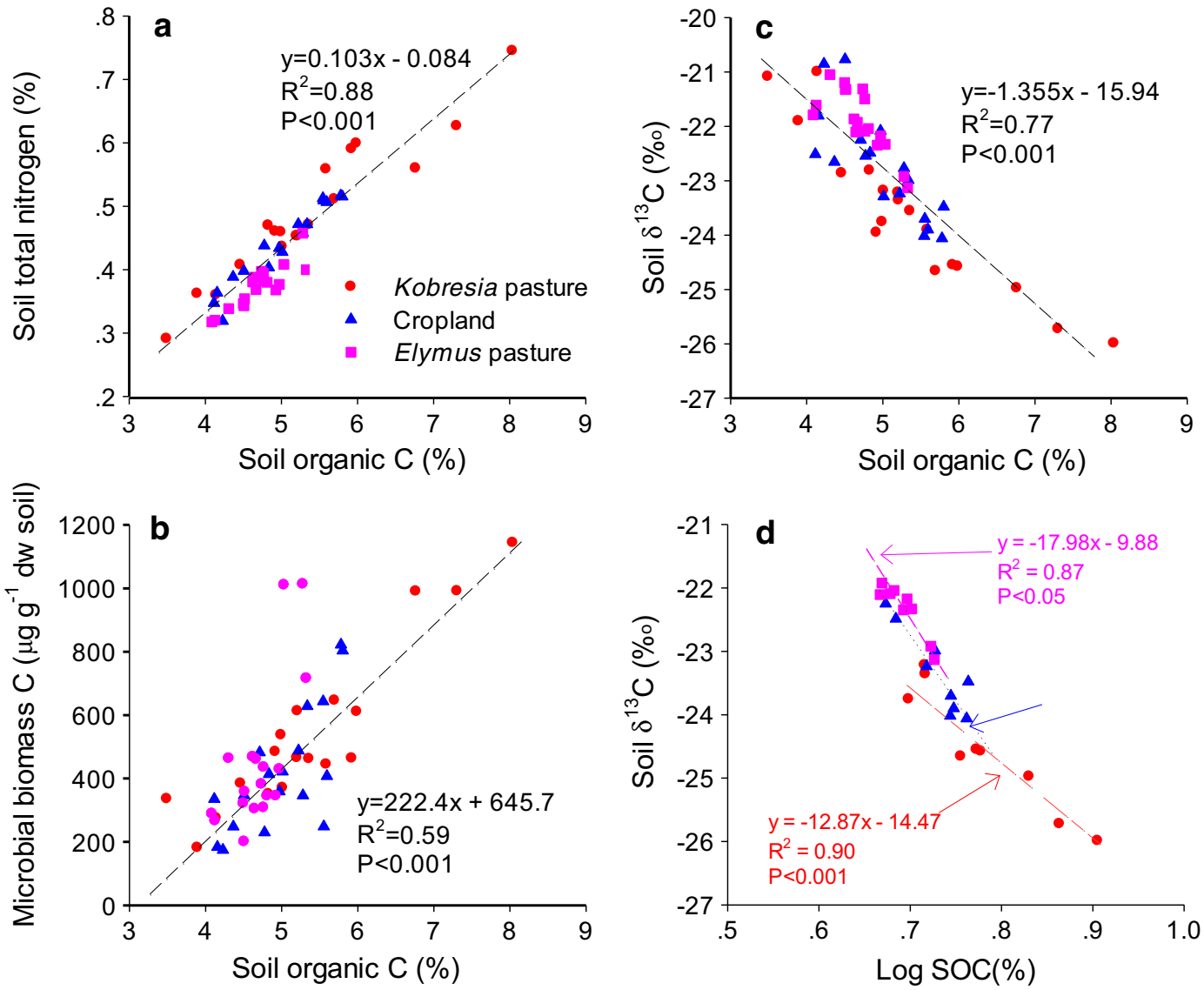

Fig. 5 Correlations between soil organic carbon with total nitrogen (a), microbial biomass carbon (b), and soil $\delta^{13} \mathrm{C}(\mathbf{c})$ across three land use types as well as relation between logarithm of $\mathrm{C}$ content and soil $\delta^{13} \mathrm{C}(\mathbf{d})$ in the top $15 \mathrm{~cm}$ for each land use type

depths (Fig. 7a). The $\mathrm{C}$ stock at the 30 -cm depth was estimated to be $15.8 \pm 0.4 \mathrm{~kg} \mathrm{C} \mathrm{m}^{-2}$ in Kobresia pasture,
$14.3 \pm 0.5 \mathrm{~kg} \mathrm{C} \mathrm{m}^{-2}$ in cropland, and $15.6 \pm 1.1 \mathrm{~kg} \mathrm{C} \mathrm{m}^{-2}$ in Elymus pasture (Fig. 7a). The microbial biomass $\mathrm{C}$
Fig. 6 Correlation between the difference in SOC $(\triangle \mathrm{SOC})$ and soil $\delta^{13} \mathrm{C}\left(\Delta\right.$ soil $\left.\delta^{13} \mathrm{C}\right)$ along the profile caused conversion from Kobresia grassland to Elymus pasture and cropland (Avena sativa)

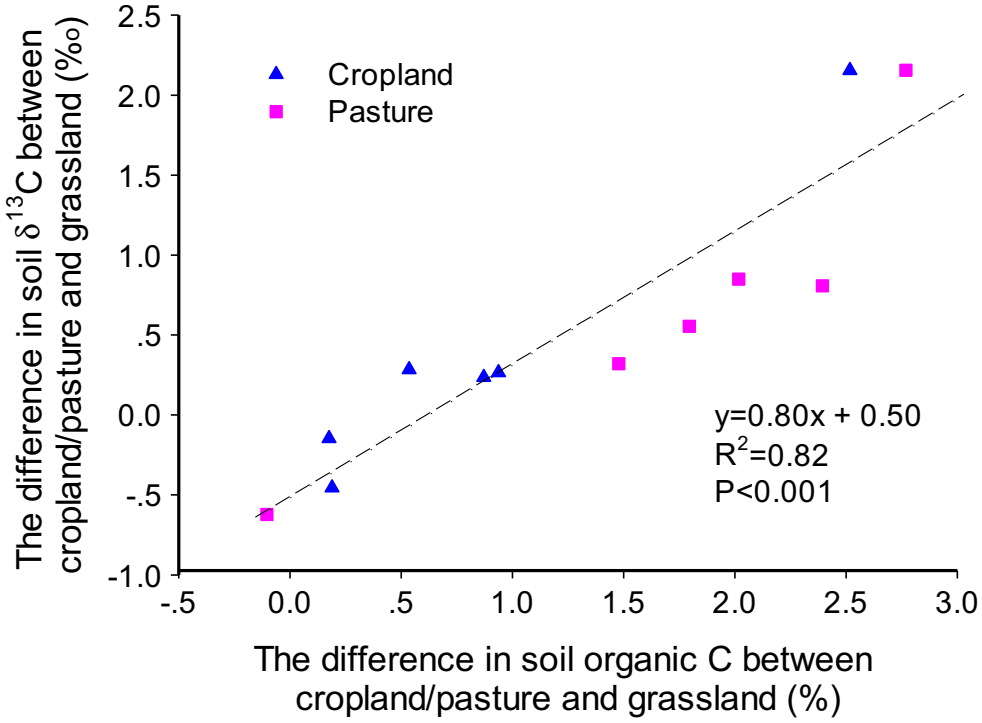


Fig. 7 The stocks of soil organic carbon (a) and microbial biomass carbon (b) in the upper $30-\mathrm{cm}$ depth after the conversion from Kobresia pasture to Elymus pasture and cropland (Avena sativa) for 10 years. Each value is means \pm SE of three replicates

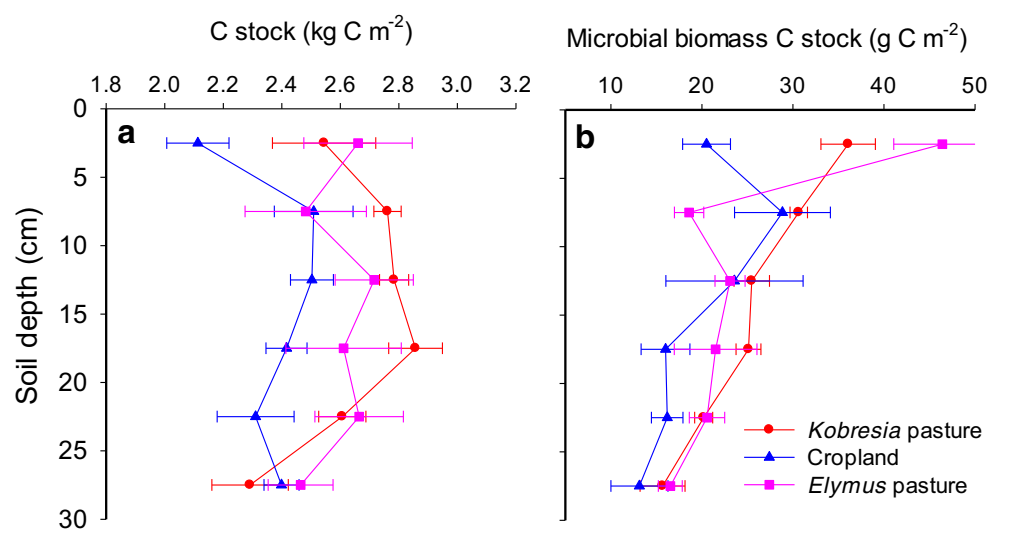

pool for Elymus pasture increased in the top 5-cm depth but strongly decreased in the second layer compared with Kobresia pasture (Fig. 7b). At the 30-cm depth, microbial biomass $\mathrm{C}$ was estimated to be $153 \pm 8.4 \mathrm{~g} \mathrm{C} \mathrm{m}^{-2}$ in Kobresia pasture, $118 \pm 24 \mathrm{~g} \mathrm{C} \mathrm{m}^{-2}$ in cropland, and $147 \pm 12.6 \mathrm{~g} \mathrm{C} \mathrm{m}^{-2}$ in Elymus pasture (Fig. 7b). Ten years after the conversion, a significant $\mathrm{C}$ loss $(10.1 \%$ of total $\mathrm{SOC})$ was observed in cropland, while there were only insignificant $\mathrm{C}$ losses $(1.6 \% \mathrm{SOC})$ in pasture. However, microbial biomass $\mathrm{C}$ was strongly reduced by $22.8 \%$ in cropland, compared to Kobresia pasture.

\section{Discussions}

Processes and mechanisms for soil C losses

The $\mathrm{C}$ stock is mainly determined by the balance between net $\mathrm{C}$ inputs to the soil as organic matter and net $\mathrm{C}$ losses from the soil as $\mathrm{CO}_{2}$. Previous studies have suggested that $\mathrm{C}$ is lost due to increased SOC decomposition caused by various cultivation practices and removal of plant biomass by annual harvesting (Geist 2006; Braimoh and Vlek 2008). In this study, greater difference in SOC, microbial biomass, soil $\delta^{13} \mathrm{C}$, and soil bulk density were mostly observed in the top $5-\mathrm{cm}$ depth, reflecting land use changes strongly affecting the surface layer, where $\mathrm{C}$ and $\mathrm{N}$ cycling could be accelerated by tillage and grazing. Further, we confirm that land use change from grasslands to agricultural uses can cause soil C loss (Geist 2006; Piñeiro et al. 2010) and specify that the magnitude of the $\mathrm{C}$ loss depends on the land use types, e.g., conversion to cropland (10\%) led to more $\mathrm{C}$ losses than Elymus pasture (1.6\%).

Higher $\delta^{13} \mathrm{C}$ of SOC generally suggests highly microbially processed and stronger SOC decomposition
(Garten et al. 2000; Poage and Feng 2004; Bowling et al. 2008). In this study, we found that a decrease of $1 \%$ of SOC led to an increase in the $\delta^{13} \mathrm{C}$ of $0.8 \%$ in montane soils. Therefore, higher $\delta^{13} \mathrm{C}$ across the soil profile in Elymus pasture compared to both Kobresia pasture and cropland (Fig. 4a) indicates enhanced SOC decomposition in pasture. This is also reflected by decreased soil C:N ratios under Elymus pasture (Fig. 2c) due to $\mathrm{C}$ depletion by enhanced decomposition. The relationship between $\delta^{13} \mathrm{C}$ and the logarithm of $\mathrm{C}$ content can reflect SOC turnover (Garten 2006; Guillaume et al. 2015). In this study, the steeper slope of cropland than that of Kobresia pasture in the top 15-cm depth demonstrates increased decomposition (Fig. 5d), but there was no significant difference between cropland and Elymus pasture. This indicates that SOC decomposition is similar in cropland and Elymus pasture, although Elymus pasture shows higher $\delta^{13} \mathrm{C}$ values.

Higher $\delta^{13} \mathrm{C}$ values across the soil profile do not reflect increased decomposition in Elymus pasture. This could be ascribed to some factors affecting soil $\delta^{13} \mathrm{C}$. First, organic matter derived from $\mathrm{C} 4$ vegetation shows higher $\delta^{13} \mathrm{C}$ values than $\mathrm{C} 3$ vegetation. However, no $\mathrm{C} 4$ plants are observed in these Kobresia pastures around the Haibei Research Station (Yi et al. 2003). Second, carbonates could contribute to higher $\delta^{13} \mathrm{C}$ in SOC in lower soil layers due to high $\mathrm{pH}$ (around 8.0) at this site, but a previous study at the same site showed that $\delta^{13} \mathrm{C}$ values in SOC after removal of carbonates with $\mathrm{HCl}$ solution are very close to ours at the corresponding soil layers (Yi 2004). This indicates that higher $\delta^{13} \mathrm{C}$ in SOC at lower soil layers could not be ascribed to inorganic $\mathrm{C}$. On the basis of $\delta^{13} \mathrm{C}$ signature in soil organic matter, Yi (2004) suggests that it may be derived from ancient C4 vegetation. Third, trampling by grazers leads to soil compaction and causes vertical shifts in soil profile. This 
also alters $\delta^{13} \mathrm{C}$ signature along the soil profile. Finally, the remaining $\mathrm{C}$ stocks in these soils are too high, and the changes of the turnover may be not visible by this approach within 10 years.

Additionally, several studies have suggested that soil $\delta^{15} \mathrm{~N}$ can reflect SOC turnover, but no strong correlation was observed between SOC contents and $\delta^{15} \mathrm{~N}$ values. This is ascribed to the complexity of the $\mathrm{N}$ cycle in terrestrial soils (Schleuss et al. 2015). Soil $\delta^{15} \mathrm{~N}$ is a result of the isotopic compositions of $\mathrm{N}$ inputs, fractionations associated with $\mathrm{N}$ transformations and $\mathrm{N}$ losses (Hobbie and Ouimette 2009; Wang et al. 2013) and is often regarded as an integrator of the $\mathrm{N}$ cycle (Robinson 2001). Therefore, significantly higher $\delta^{15} \mathrm{~N}$ in the upper 5 -cm soil depth in pasture than that in grassland (Fig. 4b) indicates accelerated $\mathrm{N}$ cycling in Elymus pasture, because grazers can increase $\delta^{15} \mathrm{~N}$ of soil by promoting $\mathrm{N}$ losses from the soil via $\mathrm{NH}_{3}$ volatilization and denitrification (Frank and Evans 1997; Cheng et al. 2009). However, no C loss occurred in Elymus pasture compared to Kobresia pasture. This indicates that soil compaction caused by trampling of yaks and goats resulted in higher soil bulk density in Elymus pasture is another pathway controlling its SOC stocks, although numerous studies suggest that grazing in Elymus pasture alters SOC stocks simultaneously through changing net primary production, $\mathrm{N}$ stocks, and increased decomposition (Piñeiro et al. 2010; McSherry and Ritchie 2013). Further studies should investigate how grazing strongly decreases SOC content yet does not change its stocks.

Despite a small amount of manure inputs to cropland, a significant $\mathrm{C}$ loss occurred in cropland compared with Kobresia pasture. This is mainly ascribed to low $\mathrm{C}$ input to the soil in croplands due to harvest of aboveground biomass. Additional explanation is that tillage increases SOC loss by breaking open aggregates to expose protected organic $\mathrm{C}$ to microbial breakdown (Tian et al. 2015). This is reflected in decrease of microbial biomass C (Fig 3a) and increase of soil $\delta^{13} \mathrm{C}$ (Fig 4a). The increased decomposition leads to rapid depletion of labile substrates (without strong input by plant residues and rhizodeposition) and thus limits microbial growth in Elymus pasture and cropland.

\section{Relevance for $\mathrm{C}$ sequestration}

Guo and Gifford (2002) highlighted the effects of land use changes on soil C stocks, showing land use changes from pasture to cropland reduces total C stocks by $59 \%$ over several decades. Our results showed a much smaller decrease of C stocks. Land use change from Kobresia pasture to Elymus pasture and cropland, 10 years ago, lead to a loss of $10 \%$ of the $\mathrm{C}$ stock in cropland and $1.6 \%$ in Elymus pasture within 30-cm depth. This corresponds to a loss of $160 \mathrm{~g} \mathrm{C} \mathrm{m}^{-2}$ year $^{-1}$ and $25 \mathrm{~g} \mathrm{C} \mathrm{m}^{-2}$ year $^{-1}$ in the upper $30-\mathrm{cm}$ soil, offsetting $\mathrm{C}$ accumulation in Kobresia pasture soils (Tian et al. 2009). Compared to previous studies in the same area, $78.6 \mathrm{~g} \mathrm{C} \mathrm{m}^{-2}$ year $^{-1}$ in the upper $40 \mathrm{~cm}$ was lost when Kobresia pasture was changed to cropland within 30 years (Li et al. 2006), half of our estimate in the 30$\mathrm{cm}$ soil profile over 10 years. Greater $\mathrm{C}$ stock loss could be due to rapid depletion of labile organic $\mathrm{C}$ at early stages of land use change. Compared to other regions, low SOC loss caused by the conversion from Kobresia pastures to cropland could be ascribed to low temperature and short vegetation period, both limiting SOC decomposition in alpine regions (Song et al. 2010; He et al. 2014).

Half of the entire Tibetan Plateau is occupied by various montane grasslands, storing about $7.4 \mathrm{Pg} \mathrm{C}$ within the upper 1-m soil depth (Yang et al. 2008). If we assume that all montane grasslands will be converted to croplands, the total soil $\mathrm{C}$ loss can be estimated to be $0.74 \mathrm{Pg} \mathrm{C}$ within 10 years. The conversion from Kobresia pasture to Elymus pasture did not lead to significant $\mathrm{C}$ losses, but the soil fertility and properties decreased due to increased bulk density and reduced microbial biomass, both key parameters to maintain soil structure and functions. In the long run, net primary production could be reduced in pasture and thus affect the $\mathrm{C}$ stock.

In summary, we conclude that the conversion of montane Kobresia grasslands to cropland decreases C stocks, while the $\mathrm{C}$ stocks were unchanged after conversion to Elymus pasture. Low $\mathrm{C}$ input due to harvest of aboveground biomass is the major pathway for decreased SOC stock in croplands, while trampling caused by grazers is responsible for unchanged $\mathrm{C}$ stock in Elymus pasture. Soil $\delta^{13} \mathrm{C}$ and $\delta^{15} \mathrm{~N}$ are useful to explore SOC dynamics caused by land use changes because they can reflect changes of $\mathrm{C}$ and $\mathrm{N}$ cycling. These findings suggest that it is essential to make a full evaluation before montane Kobresia grasslands will be converted to cropland, especially in sensitive ecosystems of the Tibet Plateau, where montane grasslands are more fragile to environmental changes and very hard to restore. 
Acknowledgments We thank Dr. Eben Goodale for the language improvements. This study was supported by the National Natural Science Foundation of China (31470560), the Knowledge Innovation Foundation Program for Outstanding Young Scholar of the Chinese Academy of Sciences (KZCX2-YW-QN302), Key Laboratory of Tropical Forest Ecology of Chinese Academy of Sciences, and the German Science Foundation priority programme 1372 "Tibetan Plateau-Formation-Climate-Ecosystems (TiP)" with the contracts KU 1184/14-1,2.

\section{References}

Babel W, Biermann T, Coners H, Falge E, Seeber E, Ingrisch J, Schleuß PM, Gerken T, Leonbacher J, Leipold T, Willinghöfer S, Schützenmeister K, Shibistova O, Becker L, Hafner S, Spielvogel S, Li X, Xu XL, Sun Y, Zhang L, Yang Y, Ma Y, Wesche K, Graf HF, Leuschner C, Guggenberger G, Kuzyakov Y, Miehe G, Foken T (2014) Pasture degradation modifies the water and carbon cycles of the Tibetan highlands. Biogeosciences 11:6633-6656

Bowling DR, Pataki DE, Randerson JT (2008) Carbon isotopes in terrestrial ecosystem pools and $\mathrm{CO}_{2}$ fluxes. New Phytol 178:24-40

Braimoh AK, Vlek PLG (2008) Land use and soil resources. Springer Science+Business Media B.V

Brookes PC, Landman A, Pruden G, Jenkenson DS (1985) Chloroform fumigation and the release of soil nitrogen: a rapid extraction method to measure microbial biomass nitrogen in soil. Soil Biol Biochem 17:837-842

Chen H, Billen N, Stahr K, Kuzyakov Y (2007) Effects of nitrogen and intensive mixing on decomposition of ${ }^{14} \mathrm{C}$-labelled maize (Zea mays L.) residue in soils of different land use types. Soil Tillage Res 96:114-123

Cheng W, Chen Q, Xu Y, Han X, Li L (2009) Climate and ecosystem ${ }^{15} \mathrm{~N}$ natural abundance along a transect of Inner Mongolian grasslands: contrasting regional patterns and global patterns. Glob Biogeochem Cyc 23(2): GB2005, doi: 10.1029/2008GB003315

Chinese Soil Taxonomy Research Group (1995) Chinese soil taxonomy. Science Press, Beijing, pp 58-147

Cotrufo MF, Conant RT, Paustian K (2011) Soil organic matter dynamics: land use, management and global change. Plant Soil 338:1-3

Frank DA, Evans RD (1997) Effects of native grazers on grassland $\mathrm{N}$ cycling in Yellowstone National Park. Ecology 78(7): 2238-2248

Garten CT (2006) Relationships among forest soil C isotopic composition, partitioning, and turnover times. Can J For Res 36:2157-2167

Garten CT, Cooper LW, Post WM III, Hanson PJ (2000) Climate controls on forest soil $\mathrm{C}$ isotope ratios in the Southern Appalachian Mountains. Ecology 81:1108-1119

Geist H (2006) Our earth's changing land: an encyclopedia of landuse and land-cover change. Greenwood Publishing Group

German DP, Chacon SS, Allison SD (2011) Substrate concentration and enzyme allocation can affect rates of microbial decomposition. Ecology 92:1471-1480
Guillaume T, Muhammad D, Kuzyakov Y (2015) Losses of soil carbon by converting tropical forest to plantations: erosion and decomposition estimated by $\delta 13 \mathrm{C}$. Glob Change Biol doi:10.1111/gcb.12907

Guo LB, Gifford RM (2002) Soil carbon stocks and land use change. Glob Chang Biol 8:345-360

Hafner S, Unteregelsbacher S, Seeber E, Xu X, Li X, Guggenberger G, Miehe G, Kuzyakov Y (2012) Effect of grazing on carbon stocks and assimilate partitioning in Tibetan montane pasture revealed by ${ }^{13} \mathrm{CO}_{2}$ pulse labeling. Glob Chang Biol 18:528-538

He YT, Xu XL, Zhang XZ, Kueffer C, Shi PL (2014) Cushion plant litter shifts nitrogen mineralization to immobilization at high but not low temperature in an alpine meadow. Plant Soil 383:415-426

Heimann M, Reichstein M (2008) Terrestrial ecosystem carbon dynamics and climate feedbacks. Nature 451:289-292

Hobbie EA, Ouimette AP (2009) Controls of nitrogen isotope patterns in soil profiles. Biogeochemistry 95:355-371

Houghton RA (1995) Changes in the storage of terrestrial carbon since 1850. In: Soils and global change. CRC Press, Inc, Boca Raton, pp 45-65

Ingrisch J, Biermann T, Seeber E, Leipold E, Li M, Ma Y, Xu XL, Miehe G, Guggenberger G, Foken T, Kuzyakov (2015) Carbon pools and fluxes in a Tibetan alpine Kobresia pygmaea pasture partitioned by coupled eddy-covariance measurements and ${ }^{13} \mathrm{CO}_{2}$ pulse labeling. Sci Total Environ 505:1213-1224

Jendinson DS, Adamas DE, Wild A (1991) Model estimated of $\mathrm{CO}_{2}$ emissions from soil in response to global warming. Nature 351:304-306

Kaiser K, Schoch WH, Miehe G (2007) Holocene paleosols and colluvial sediments in Northeast Tibet (Qinghai Province, China): properties, dating and paleoenvironmental implications. Catena 69(2):91-102

Kirschbaum MUF (2004) Soil respiration under prolonged soil warming: are rate reductions caused by acclimation or substrate loss? Glob Chang Biol 10:1-8

LeCain DR, Morgan JA, Schuman GE, Reeder JD, Hart RH (2002) Carbon exchange and species composition of grazed pastures and exclosures in the short grass steppe of Colorado. Agric Ecosyst Environ 93:421-435

Li YN, Zhao XQ, Cao GM, Zhao L, Wang QX (2004) Analyses on climates and vegetation productivity background at Haibei Alpine Meadow Ecosystem Research Station. Plateau Meteorology 23:558-567

Li YM, Cao GM, Wang YS (2006) Effects of reclamation on soil organic carbon in Haibei alpine meadow. Chin J Ecol 25: 911-915

Liu JY, Kuang WJ, Zhang ZX, Xu XL, Chen YW, Jia N, Zhou WC, Zhang SW, Li RD, Yan CZ, Wu SX, Shi XZ, Jiang N, Yu DS, Pan XZ, Chi WF (2014) Spatiotemporal characteristics, patterns and causes of land use changes in China since the late 1980s. Acta Geograph Sin 69:3-14

McSherry ME, Ritchie ME (2013) Effects of grazing on grassland soil carbon: a global review. Glob Chang Biol 19:1347-1357

Miehe G, Miehe S, Kaiser K, Liu JQ, Zhao XQ (2008) Status and dynamics of the Kobresia pygmaea ecosystem on the Tibetan plateau. Ambio 37:272-279

Miehe G, Miehe S, Kaiser K, Reudenbach C, Behrendes L, La D, Schlütz F (2009) How old is pastoralism in Tibet? an 
ecological approach to the making of a Tibetan landscape. Palaeogeogr Palaeoclimatol Palaeoecol 276(1):130-147

Miehe G, Bach K, Miehe S, Kluge J, Yang Y, La D, Co S, Wesche K (2011) Alpine steppe plant communities of the Tibetan highlands. Appl Veg Sci 14:547-560

Miehe G, Miehe S, Böhner J, Kaiser K, Hensen I, Madsen D, Liu JQ, Opgenoorth L (2014) How old is the human footprint in the world's largest alpine ecosystem? A review of multiproxy records from the Tibetan plateau from the ecologists' viewpoint. Quat Sci Rev 86:190-209

Newton JD, Wyatt FA, Brown AL (1945) Effects of cultivation and cropping on the chemical composition of some western Canadian prairie province soils. Sci Agric 25:718-737

Piñeiro G, Paruelo JM, Oesterheld M, Jobbágy EG (2010) Pathways of grazing effects on soil organic carbon and nitrogen. Rangel Ecol Manag 63:109-119

Poage MA, Feng XH (2004) A theoretical analysis of steady $\delta^{13} \mathrm{C}$ profiles of soil organic matter. Glob Biogeochem Cyc 18: GB2016, doi:10.1029/2003GB002195

Reid RS, Thornton PK, McCrabb GJ, Kruska RL, Atieno F, Jones PG (2004) Is it possible to mitigate greenhouse gas emissions in pastoral ecosystems of the tropics? Environ Dev Sustain 6: 91-109

Robinson D (2001) $\delta^{15} \mathrm{~N}$ as an integrator of the nitrogen cycle. Trends Ecol Evol 16(3):153-162

Sanaullah M, Blagodatskaya E, Chabbi A, Rumpel C, Kuzyakov Y (2011) Drought effects on microbial biomass and enzyme activities in the rhizosphere of grasses depending on plant community composition. Appl Soil Ecol 48:38-44

Šantrůčková H, Bird MI, Lloyd J (2000) Microbial processes and carbon-isotope fractionation in tropical and temperate grassland soils. Funct Ecol 14:108-114

Schleuss P, Heitkamp F, Sun Y, Miehe G, Xu XL, Kuzyakov Y (2015) Nitrogen uptake in an alpine Kobresia pasture on the Tibetan Plateau: localisation by ${ }^{15} \mathrm{~N}$ labelling and implications for a vulnerable ecosystem. Ecosystems. doi:10.1007/ s10021-015-9874-9

Song MH, Jiang J, Cao GM, Xu XL (2010) Effects of temperature, glucose and inorganic nitrogen inputs on carbon mineralization in a Tibetan alpine meadow soil. Eur J Soil Biol 46:375-380

Stockmann U, Adams MA, Crawford JW, Field DJ, Henakaarchchi N, Jenkins M, Minasny B, McBratney AB, de Remy de Courcelles V, Singh K, Wheeler I, Abbott L, Angers DA, Baldock J, Bird M, Brookes PC, Chenu C, Jastrow JD, Lal R, Lehmann J, O’Donnell AG, Parton WJ, Whitehead D, Zimmermann M (2013) The knowns, known unknowns and unknowns of sequestration of soil organic carbon. Agric Ecosyst Environ 164:80-99

Tarnocai C, Canadell JG, Schuur EAG, Kuhry P, Mazhitova G, Zimov S (2009) Soil organic carbon pools in the northern circumpolar permafrost region. Global Biogeochem Cycles 23:GB2023, doi:10.1029/2008GB003327

Tian YQ, Xu XL, Song MH, Zhou CP, Gao Q, Ouyang H (2009) Carbon sequestration in two alpine soils on the Tibetan plateau. J Integr Plant Biol 51(9):900-905

Tian J, Pausch J, Yu G, Blagodatskaya E, Gao Y, Kuzyakov Y (2015) Aggregate size and their disruption affect ${ }^{14} \mathrm{C}$-labeled glucose mineralization and priming effect. Appl Soil Ecol 90:1-10

Unteregelsbacher S, Hafner S, Guggenberger G, Miehe G, Xu XL, Liu J, Kuzyakov Y (2012) Response of long-, medium- and short-term turnover processes of the carbon budget to overgrazing on the Tibetan plateau. Biogeochemistry 111: 187-201

Vance ED, Brookes PC, Jenkinson DS (1987) An extraction method for measuring soil microbial biomass C. Soil Biol Biochem 19(6):703-707

Wang W, Fang JY (2009) Soil respiration and human effects on global grasslands. Glob Planet Chang 67(1-2):20-28

Wang SP, Wilkes A, Zhang ZC, Chang XF, Lang R, Wang YF, Niu HS (2011) Management and land use change effects on soil carbon in northern China's grasslands: a synthesis. Agric Ecosyst Environ 142:329-340

Wang LX, Okin GS, D’Odorico P, Caylor KK, Macko SA (2013) Ecosystem-scale spatial heterogeneity of stable isotopes of soil nitrogen in African savannas. Landsc Ecol 28(4):685-698

WBGU Special Report (1998) The accounting of biological sinks and sources under the Kyoto Protocol. WBGU, Bremerhaven

WRB (1998) World reference base for soil resources. FAO/ISRIC/ ISSS, Rome

Wu J, Jörgensen RG, Pommerening B, Chaussod R, Brookes PC (1990) Measurement of soil microbial biomass-C by fumigation-extraction - an automated procedure. Soil Biol Biochem 22:1167-1169

Wu HB, Guo ZT, Peng CH (2003) Distribution and storage of soil organic carbon in China. Global Biogeochem Cycles 17:1-11

Yang YH, Fang JY, Tang YH, Ji CJ, Zheng CY, He JS, Zhu B (2008) Storage, patterns and controls of soil organic carbon in the Tibetan grasslands. Glob Chang Biol 14:1592-1599

Yi X (2004) Stable carbon isotopic composition in soil organic carbon and $\mathrm{C} 3 / \mathrm{C} 4$ source variations at the Haibei Alpine Meadow. Acta Bot Boreal 25(2):336-342

Yi X, Yang Y, Zhang X, Li L, Zhang L (2003) No C4 plants found at the Haibei Alpine Meadow Ecosystem Research station in Qinghai, China: evidence from stable carbon isotope studies. Acta Bot Sin 45(11):1291-1296

Zhang JW (1988) Vegetation of Xizang Science Press, Bejing

Zhang YL, Li BY, Zheng D (2002) A discussion on the boundary and area of the Tibetan plateau in China. Geogr Res 21:1-8

Zhou XM (2001) Alpine Kobresia meadows in China. Science Press, Beijing 